\title{
O que fazer?
}

What to do?

\section{JUNIOR CUNHA}

Deu-me uma vontade horripilante de escrever e, confesso que inicialmente, pensei em um texto fenomenal; pretendia escrever uma história de amor, agora nem mesmo lembro-me dela. Mas, a vontade de escrever persiste. Então aqui estou sem ideias, sem motivos, sem inspiração, apenas movido por uma vontade, um desejo incontrolável, insaciável, irrepreensível de escrever.

O que fazer nestas horas? Esta é a pergunta que impregnou meus alucinados pensamentos. Talvez, e caso consiga responde-la terei, sabe-se lá, um minuto de paz. Esta atordoante questão não me sai da mente - o que fazer nestas horas? horas essas tão confusas, tão insatisfatórias. E que diabos! Pereço por não ter um estímulo qualquer, uma força abrupta que imprevisivelmente brote de minha imaginação, um cortejo alegre de meus fascinantes devaneios, e ao invés, só o que tenho é um desejo. Este que tem me ferido a carne em busca de ser saciado. Não o posso.

Como saciar esse desejo? Como sanar a vontade de escrever? Receio que só precise de um bom conhaque, ou ainda, uma boa garrafa de vodka. E se isso não adiantar, e se de fato eu tenha que escrever? Sobre o que escreverei? Que droga, lá vou eu novamente ser tomado pelo desespero. Algo horrendo toma conta de mim e eu saio digitando como louco, o resultado, este relato horrível feito com palavras sem sentidos, apenas para conter uma maluquice qualquer, de um idiota qualquer, que tinha um desejo qualquer.

São tantos os quaisquer, são tantas possibilidades, tantos infinitos, e eu em busca de apenas um contentamento; quero apenas me alegrar pela realização de um desejo. Mas, as perguntas não querem calar: o que fazer? O que escrever? Sobre o que escrever? São tamanhas as dúvidas, e tão imprecisas as certezas que me vejo perdido.

$\mathrm{O}$ desejo se vai. $\mathrm{O}$ contentamento não importa mais. Almejar a alegria já não faz mais sentido. Tudo o que me resta agora é frustração, fúria pelo meu ser insignificante, cólera diante da incapacidade que repousou sobre mim. Mesmo estando sozinho em meu quarto meu eu se dissipa em meio à multidão. Torno-me apenas mais um, sou novamente parte do comum que são todos. Por outro lado, sem agora me valer de nada, sei sobre o que escrever. Por mais que isso me doa, ou que meu ser relute contra essa decisão, contudo, não escreverei.

\footnotetext{
${ }^{1}$ Graduando do Curso de Licenciatura em Filosofia e bolsista do Projeto Teatro em Ação na Universidade Estadual do Oeste do Paraná. E-mail: juniorlcunha@hotmail.com.
} 
Insanidade de minha parte? Talvez. Falta de sensatez? Tolice? Contradição de princípios? Chame do quiser, não ligo. Não escreverei pelo único e simples fato de já ter feito o que deveria fazer. Buscar por algo e quando encontrar não dar à mínima, é apenas um efeito colateral de quem não tem a certeza pelo o que busca. Sei que escrevi bobagens ao procurar por algo sério para escrever. Porém, assumo que tais bobagens foram espontâneas, ao contrário do que seria caso escrevesse sobre alquilo que encontrei.

Submissão: 23. 01. 2018 / Aceite: 02. 02. 2018. 